\title{
Indigenous Sanction of Expulsion in Central Aceh District (Human Rights Perspective)
}

\author{
Valentina Shanty \\ (Magister of Legal Studies, Postgraduate Program of \\ Syiah Kuala University, Darussalam Banda Aceh, \\ Email: shantyvalentina@gmail.com) \\ Adwani Adwani \\ (Magister of Legal Studies, Postgraduate Program of \\ Syiah Kuala University, Darussalam Banda Aceh, \\ Email:adwani@unsyiah.ac.id) \\ Azhari Yahya \\ (Magister of Legal Studies, Postgraduate Program of \\ Syiah Kuala University, Darussalam Banda Aceh, Email: \\ azhari.yahya@unsyiah.ac.id)
}

\begin{abstract}
:
Aceh Province as an Islamic Sharia Regional has culture and customs based on the values of the Quran and Hadith. For the Acehnese people, customs and laws cannot be totally separated that Acehnese customary law continues to grow until the birth of Acehnese Qanun Number 9 of 2008 concerning the Development of Indigenous and Customary Life. In the implementation, the customary sanctions experience some obstacles due to their unwritten characteristic that made them slightly shifted by the presence of national law. As what happens nowadays in Central Aceh District which is famous with its traditional values, there found legal issues for the customary instrument (Sarak Opat) when the customary sanctions considered discriminatory and arbitrary. Therefore, the settlement of customary disputes must be in accordance with humanitarian principles prioritizing the principle of deliberation and peace although many obstacles still exist at the level of implementation because of lack of understanding by both community and customary instruments related to the implementation of customary itself.
\end{abstract}

\section{Keywords:}

Custom, Indigenous Sanction, Human Rights, Aceh

al-1hkâm Vol.13 No.2 December 2018

DOI 10.19105/al-ihkam.v13i2.1828 
Indigenous Sanction of Expulsion

\begin{abstract}
Abstrak:
Provinsi Aceh sebagai Daerah Syariat Islam memiliki Budaya dan Adat Istiadat yang berdasarkan pada nilai- nilai Al-Qur'an dan Hadits. Bagi masyarakat Aceh, Adat dan Hukum tidak dapat dipisahkan, sehingga Hukum Adat Aceh terus berkembang dengan lahirnya Qanun Aceh Nomor 9 Tahun 2008 tentang Pembinaan Kehidupan Adat dan Adat Istiadat. Dalam penerapan sanksi adat mengalami kendala dikarenakan sifatnya yang tidak tertulis sehingga mengalami pergeseran dengan hadirnya hukum nasional. Seperti halnya di Kabupaten Aceh Tengah yang sangat kental dengan nilai-nilai adatnya, saat ini timbul permasalahan hukum bagi Perangkat Adat (Sarak Opat), jika sanksi adat yang diputuskan bersifat diskriminatif dan sewenang-wenang. Oleh karena itu, penyelesaian sengketa adat harus sesuai dengan asas-asas kemanusiaan yang mengedepankan prinsip musyawarah dan perdamaian, walaupun masih banyak kendala yang dihadapi dalam tataran implementasinya karena kurang pemahaman baik oleh masyarakat maupun perangkat adat terkait pelaksanaan hukum adat itu sendiri.
\end{abstract}

\title{
Kata Kunci:
}

Adat, Sanksi Adat, Hak Asasi Manusia, Aceh

\section{Introduction}

Human Rights has experienced rapid development along with the emergence of the community need for the protection of their rights as citizens. This protection is guaranteed by every country in the world and is the duty of the government to provide fulfillment, enforcement, and protection of every citizen. This could be done by considering the interests/rights of other people and the surrounding community so there would be no violations and arbitrations in the name of human rights. One of the community needs related to the fulfillment of human rights is the existence of legal protection for the community in completing social matters both through litigation and non-litigation ways. The procedure for settlement is not immune from the development of legal pluralism in Indonesia which is indicated by the existence of state law on the one hand and various forms of rules in society such as customary law on the other sides.

In Article 18 B paragraph (2) of the 1945 Constitution, it is stated that the state recognizes and respects customary law community units and their traditional rights as long as being alive 
and in accordance with the development of people and the principle of the Unitary State of the Republic of Indonesia as stipulated in the Law. Aceh as one of the provinces that applies Islamic law required regional regulation, hereinafter referred as Qanun, which is a manifestation of the implementation of community life related to the traditional life which is one of the distinctive features of Aceh. The spirit of upholding Islamic law in the context of customary law has become a traditional character of Aceh so that custom and Islamic law become inseparable from one and another. For this reason, the Acehnese Government established the Acehnese Qanun Number 9 of 2008 concerning Customary Development which becomes the basis for enforcing Islamic Sharia values so that the Acehnese people remain alive in Islamic values.

Customary law itself is used to solve problems in community social life which are possible to be resolved through deliberation and consensus. Settlement of customary disputes is carried out if someone in the indigenous community commits customary violations including: disputes within the household; family disputes related to faraidh (the division of the estate); disputes between residents; khalwat (perverted deed); disputes about property rights; family theft (minor theft); property dispute of sehareukat; minor theft; theft of livestock animal, agriculture and forest; disputes at sea; disputes on the market; mild persecution; forest burning (on a small scale, harming indigenous communities); harassment, slander incitement, and defamation; light scale of environmental pollution; threatening and threat (depending on the type of threat); and other disputes that violate customs. ${ }^{1}$

Based on the type of violation, customary settlement is carried out in stages by referring to deliberations and consensus which are peaceful but binding with several alternatives. Examples of this are suggestion and reprimand, declaring apologies, compensation, fines, ostracism or expulsion from the village, revocation of traditional titles, and other forms of sanctions according to local customs.

One of the problems that occur in the settlement of customary cases is that the mechanism for resolving and implementing

1 Acehnese Qanun Article 13 Number 9 of 2008 concerning the Development of Indigenous and Customary Life 
customary sanction has not yet fully proceeded in accordance with the spirit of development which is the goal of the custom itself. Customary law that is not recorded can be misused by certain parties in executing the perpetrator of customary violations as to create legal uncertainty for customary violators and implementers of customary law itself. Customary law and sanctions can have an impact on discriminatory treatment if it is not carried out wisely.

Regarding the cases of customary sanction in the form of ostracism or expulsion from certain villages which are still common in Aceh, the Chairperson of the Acehnese Customary Council, Badruzzaman, stated that sometimes the reason and system of expulsion are not necessarily true. Especially now, there are many young village leaders (keuchik) who are less experienced in the field of customary law. Expulsion can be carried out if the perpetrator repeats an offence. Moreover, it should be after being reminded not to repeat his or her action ${ }^{2}$. In its implementation, sanctions of expulsion are still recognized and justified but with strict provisions and conditions by referring to the types of customary violations committed by a person so that they can be sentenced according to customary law as stipulated in the Qanun.

Central Aceh as one of the Districts in Aceh Province has its own customary law called Gayo Customary Law. This law regulates the sanction of expulsion termed with Parak defined as the heaviest customary sanction (jeret naru) ${ }^{3}$. The sanction for expulsion is still valid in some parts of the Central Aceh region. The majority of cases of expulsion that occur in Gayo community are caused by marriages of fellow tribes who are prohibited in local customary law. Most of the Gayo indigenous people adhere to the exogamy marriage system, namely the prohibition of marriage in one village because of the assumption as one offspring. ${ }^{4}$

This study aims to provide an overview of the facts accompanied by an analysis of the implementation of customary

\footnotetext{
2 Bakri: "Ketua Majelis Adat Aceh: Tak Boleh Sembarangan Usir Orang.", Tribun Aceh, March 2nd, 2013, http://aceh.tribunnews.com/2013/03/02/ketua-maa-takboleh sembarangan-usir-orang

${ }^{3}$ Central Aceh District Qanun Number 10 of 2002 concerning Gayo Customary Law 4 Jamal, Executive Board of the Gayo Indigenous Assembly Secretariat, Takengon, interviewed on February $7^{\text {th }}, 2018$
} 
sanction in efforts to resolve traditional disputes so that they continue to respect the basic values of human rights. The analysis will be linked to legislation and legal theories in a complete and systematic manner.

\section{Methodology}

This research is a type of empirical juridical research, namely an empirical law research on the behaviour of the community members. ${ }^{5}$ Data for this study were obtained through field research based on interviews and literature reviews. The data that has been collected is then sorted systematically and elaborated descriptively to achieve the desired objectives of this study.

\section{Theoretical Framework in Regard to Custom and Human Rights}

Human rights recognize every difference and need in customary law communities that must be protected by law, society and government. This must be implemented as mandated in the constitution that customary law will continue to be recognized as long as it is in line with the era and does not violate the principle of the Unitary State of the Republic of Indonesia as stipulated in the Law. Indonesia as a country with Pancasila (the five-state fundamental theories) philosophy and believe to the One God accepts that every rule must be guided by religious values.

The application of customary law, which is a good habit agreed upon in a community group with the aim of achieving public order, must continue to be respected and developed as a legal system that goes hand in hand with national law. This is in line with the values of human rights which require respect for the rights of others in addition to the personal rights inherent in everyone. Customary rights that are actually still valid and upheld in the life of indigenous people must be respected and protected by taking the legal and regulatory aspects into account.

\footnotetext{
5 Asri Wijayanti and Lilik Sofyan Achmad, Strategi Penulisan Hukum, (Lubuk Agung: Bandung, 2011) page 97.
} 


\section{Human Rights Review of the Implementation of Customary Sanction in Central Aceh District}

Central Aceh District is one of the Districts in Aceh Province which is inhabited by most of the people of the Gayo Tribe. The cultural system of the Gayo community is basically based on Islamic sharia values containing knowledge, beliefs, values, religion, norms, rules, and laws that become reference for behavior in people's lives. ${ }^{6}$ Therefore, Gayo customary law is a rule or action that is based on Islamic law then obeyed, glorified, adhered to and carried out consistently and thoroughly by the Gayo community.

In the culture of Gayo society, custom and law (edet urum ukum) cannot be separated.7 There found a popular principle saying "Edet kuet muperala agama, rengang edet benasa nama, edet munukum bersifet ujud, ukummunukum berseifet kalam" (custom is guided by religious law. When custom is not strong, the name perishes. Punishing custom is definite, religious law is certain), "Edet mungenal, ukum mubeza" (custom looks for what is right and wrong, while the law distinguishes between right and wrong). ${ }^{8}$

Gayo customary law is believed to have a very important role in the law enforcement. Law must go hand in hand with custom as a law that lives and develops in society. Customary law that continues to experience changes and updates in accordance with the period in a multicultural society has inspired Government of Central Aceh District to start codifying Gayo Customary Law. It is in form of Regional Regulations compiled as Central Aceh District Qanun Number 10 of 2002 concerning Gayo Customary Law. In the Qanun, customary law consists of values and socio-cultural norms which live and develop in the Central Acehnese Gayo community.

Customary law is carried out by customary institutions called Sarak Opat. The Sarak Opat element that exists in the Gayo community consists of reje (the prince), imem, petue, and rakyat genap mupakat (sudere). The Sarak Opat has the role of preventing and acting against illegal acts (sumang), implementing customary law, tradition, habit

\footnotetext{
${ }^{6}$ Sukiman," Nilai- Nilai Pembangunan Islam dalam Masyarakat Adat Gayo", Miqoot, Vol. XXXVIII, No.1, (January - June, 2014), page. 216.

${ }^{7}$ Ibid, page. 217.

${ }^{8}$ Sukiman, Op.Cit, page. 218.
} 
and customary sanction and resolving cases that violate custom. In completing customary cases, the Sarak Opat institution is responsible to solve cases according to customary law, custom, and habits in a certain period of time. The Sarak Opat also has the authority to impose a customary sanction in the process of overcoming the case based on content of the Central Aceh Qanun Number 10 of 2202 concerning Gayo Customary Law.

In its development, Gayo Customary Law began to find obstacles for its implementation, such as the case in Kelitu Village, Bintang Regency, Central Aceh District. The result of the customary court decision against a customary violator who has committed immoral or sumang in the village with customary sanction was in form of payment of fines of 1 (one) buffalo and the provision of food for villagers. The recovery process is often called "floor cleaning" as a condition for eliminating the village from violations that have been committed. ${ }^{9}$ This later became a legal problem when the perpetrator of the customary violations did not accept the customary decision. $\mathrm{S} /$ he then reported to the police that reje as the leader of the Sarak Opat deliberation organization had carried out a form of arbitrariness in his position as custom protector by extorting the perpetrator of customary offences. The perpetrator of customary violation assumed that there has been an attempt to discriminate against sanction that incriminated him/her. Then, based on this report, the local reje was detained for some periods as the customary sanction imposed on a customary offender was deemed not in accordance with the law. ${ }^{10}$

Discrimination was alleged to the reje because it was considered to force the perpetrator to pay a fine without regard to the actor's financial strength. The decision was considered burdensome and thought as a form of intimidation. In Central Aceh District Qanun Number 10 of 2002 concerning Gayo Customary Law, it justifies the existence of appropriate forms of the customary sanction imposed on the perpetrator of sumang kemalun edet, ${ }^{11}$ so that the perpetrator of

\footnotetext{
${ }^{9}$ Jamal, Executive Board of the Gayo Indigenous Assembly Secretariat, Takengon, interviewed on February $7^{\text {th }}, 2018$

${ }^{10}$ Tengku Usman, Head of Kelitu Village, Takengon, interviewed on February $8^{\text {th }}$, 2018

${ }^{11}$ Article 15 Qanun of Central Aceh District Number 10 of 2002 concerning Gayo Customary Law
} 
sumang regrets their actions. The imposition of sanction can be done with notes through several stages that must be passed by the Sarak Opat.

According to the result of an interview with Mr. Ibnu Hajar, reje of Bujang Village, Lut Tawar Regency, the Sarak Opat institution has implemented traditional rules which have been handed down for generations by ancestors until now. The Sarak Opat institution in the village was formed based on a decree of the Islamic Sharia Office consisting of reje, imem, Rakyat Genap Mupakat (RGM), youth leaders, and village security unit. ${ }^{12}$ In carrying out its duties, the Sarak Opat of Bujang Village in Lut Tawar Regency has imposed several customary sanctions on cases that have occurred in the territory of its customary law communities.

In some cases, the settlement process can be resolved with peace, but a few are in trouble because of differences of opinion over sanction imposed. One of them is the sanction of expulsion that has been carried out against a native woman of the village who committed adultery with a young man from outside the village. Both of them were arrested by villagers and handed over to reje to be confronted with customary deliberations. From the result of the deliberation, it was decided that both were sanctioned by customary expulsion and need to be responsible for the action. In the process of execution, the man refused to be responsible and escaped due to the objection to the result of the customs decision. Likewise, the woman refused to leave the village as she did not have another place to live in. ${ }^{13}$

The Sarak Opat institution itself could not force the execution. It was just the result of the deliberation state that if customary sanctions were not implemented, the villagers would isolate the families of customary offenders, for example by boycotting events carried out by families of traditional offenders. The Sarak Opat institution was urged to be firm but on the other hand, it also needs to consider humanitarian aspects. A female offender who was a native resident of the village was a widow with 1 (one) child who lived in a weak economic condition as a street sweeper and did not have his

\footnotetext{
${ }^{12}$ Ibnu Hajar, Reje of Bujang Village, Takengon, interviewed on February $7^{\text {th }}, 2018$
}

${ }^{13}$ Ibnu Hajar, Reje of Bujang Village, Takengon, interviewed on February $7^{\text {th }}, 2018$ 
own place to live. Customary offender along with her child has been staying at her parents' home. If she was forced to leave the village, this could cause other problems, so that the Sarak Opat institution did not force the implementation of sanction.

Another result of the interview showed that the result of customary deliberations was difficult to implement because most of customary provisions were not written, so that in imposing customary sanction, there were often debates in the community. If the customary sanction befalls to the relatives/family of traditional leaders in the village, it may potentially cause injustice. ${ }^{14}$ The absence of clear boundaries regarding the regulation of customary sanction can lead to discrimination that it has the potential to create turmoil in the community. For this reason, the Sarak Opat institution as the organizer of the government is obliged to be fair and wise in deciding every case.

The development of discourse to standardize the principles of the customary law as a reference for the Sarak Opat institution, given that the current national law has undergone development, is expected to be able to provide certainty in providing legal options for communities to settle customary cases as stipulated in the customary law of qanun. ${ }^{15}$ Therefore, Gayo customary law which is guided by Islamic law will be maintained and accepted as a law that applies to the community. For example, Asir-Asir Atas Village of Lut Tawar Regency still applies the belief that the laws established by ancestors and previous ancestors are true and categorized as holy laws, although in its development, new problems tend to arise in the application of the customary law in multicultural societies ${ }^{16}$. An example of the application of traditional jeret naru sanction is the parak sanction as the heaviest customary sanction in Gayo customary law. It applies to couples who get married to fellow clans/belah. They would be urged to be expelled from the village and not allowed to return for a certain period of time.

\footnotetext{
${ }^{14}$ Ibnu Hajar, Reje of Bujang Village, Takengon, interviewed on February $7^{\text {th }}, 2018$

15 Ampera, Reje of Asir-Asir Atas Village, Takengon, interviewed on February 7th, 2018

16 Ampera, Reje of Asir-Asir Atas Village, Takengon, interviewed on February 8th, 2018
} 
Most of Gayo people still maintain an exogamous marriage system. It requires someone to look for a spouse (prospective husband or future wife) from other belah that is considered as a bloodline. The ban aims to keep the daughters from surrounding disturbances, avoid free association, create smart offspring, consider the surrounding community as brother/sister, and to preserve the tradition that has been inherited from their former ancestors. Most of Gayo people in Central Aceh who implement this marriage system agree to keep maintaining the culture that has been carried out for generations. They are also committed with the consequence that if it happens to one of their family members who break the tradition, they have to give up (jeret naru customary sanction) from their area during the time determined by the traditional Sarak Opat institution. ${ }^{17}$

In the modern era like now, the customary provisions in the form of expulsion for people who violate the provisions related to marriage with a spouse from 1 (one) village/area cause new polemic in the community. It is mainly because it turns out that it doesn not only apply for settling villagers as happened in Asir-Asir Atas Village. Residents who have migrated will also be subjected to similar sanctions if the spouses are from the same bloodlines of both father and mother side or coming from the same area. ${ }^{18}$ In its development, this has caused a controversy. In fact, there are some parties who have dared to try manipulating the customary law in order to avoid the traditional sanction of jeret nuru. This is done by changing the data from the area of origin of the bride or bridegroom. ${ }^{19}$

If viewed from the perspective of human rights, the implementation of the jeret nuru sanction in the form of expulsion carried out due to the marriage of fellow citizens/villages in a pluralistic society, such as the Gayo community, would certainly be a legal challenge. In Article 10 of Law Number 39 of 1999 concerning Human Rights, it is stated that every person has the right to form a family and to continue descent through a legal marriage.

\footnotetext{
17 Zainal Abidin, Indigenous People in Bujang Village, Takengon, interviewed on February 10th, 2018

18 Ampera, Reje of Asir-Asir Atas Village, Takengon, interviewed on February $8^{\text {th }}$, 2018

${ }^{19}$ Amirsyam, Gayo Traditional Leader, Takengon, interviewed on February 9th, 2018
} 
Additionally, in Law No. 1 of 1974, there is no prohibition for someone who wants to get marriage except between two people who are related to blood both straight down and up, blood-related in a sideline, related to fines, related to one another, nephew form the wife in the case of a husband who has more than one wife, and finally one whose religion forbids to carry out any marriage.

The nowadays development of changing lifestyles of people in the age of globalization and modernity with various advances in technology, information and transportation, as well as the incoming of people from outside the region such as Aceh and Java who migrated to the Gayo highlands, tend to shift the existing culture. The implementation of exogamy marriage to the Gayo tribe is in turn difficult to maintain because the position of belah in the Gayo community does not use clans as in Batak custom. It makes any prospective spouse from outside Gayo tribe are not known from where they come from. As they conduct mixed marriage, what was once a genealogical indigenous community based on blood ties will then disappear naturally. ${ }^{20}$ This is indicated by the shifting paradigm on the prohibited values about the marriage of fellow villagers. Only some places still perform the customary provisions. The majority of regions in Central Aceh have begun to abandon the custom.

The prohibition on the marriage of fellow villagers was originated from the beliefs of the Gayo people that all forms of customary rules established in the Gayo community were rooted in the provision of Religion. The Gayo community once believed that people in the same village had the family ties. Marriage in the family ties was believed to have caused a lot of harm. Concern arises when there was a quarrel between couples because that can damage relations between families. ${ }^{21}$

Along with the times and advances in technology, Gayo traditional leaders also realize that transcription on the principles of customary law is needed in the community. This is a form of customary rules. Many people do not know the customary rules so

\footnotetext{
${ }^{20}$ Jamal, Executive Board of the Gayo Indigenous Assembly Secretariat, Takengon, interviewed on February $9^{\text {th }}, 2018$

${ }^{21}$ Tgk. Qadri, Imem of Asir-Asir Atas Village, Takengon, interviewed on February $8^{\text {th }}$, 2018
} 
they choose to resolve disputes through litigation. In addition, the need for village regulations can be both reference and limit for village officials, in this case, the Sarak Opat institution, for establishing customary sanction for their communities in order to be more legally certain. The principle transcripted including customary sanction is needed as a basis for traditional leaders in determining customary rules in accordance with the agreement. This is an effort to prevent the violation of human rights due to unclear legal rules which potentially reduce, limit or eliminate one's rights. ${ }^{22}$

The importance of establishing sanction for customary law in the written form is a demand in this situation. This also guarantees a legal certainty for nowadays people who have undergone changes and assimilation of culture. Therefore, individuals or groups living in certain social areas can choose one of the laws that they feel more effective in resolving disputes. The principle of legal certainty here is considered very essential so that the rights of individuals to obtain justice are fully fulfilled without discrimination.

Gayo customary sanction imposing on acts of violating custom (sumang) is a settlement that is done wisely. One of the sanctions imposed on customary offenders is parak sanction or expulsion which is an inseparable part of Gayo customary sanction and is still recognized in the Gayo customary community. It means that they should be respected and protected as long as they are still recognized and accepted by customary law communities. Meanwhile, law enforcement officials must provide an opportunity for the Sarak Opat institution to resolve customary disputes by means of consensus agreement. They also need to establish valid customary sanction as long as it is carried out through the right and not arbitrary process.

Parak customary sanction itself is a form of punishment carried out with full willingness. The perpetrator who has been sentenced to parak can be recognized again as villagers on the condition that they have finished serving a sentence (parak) which has been decided through a customary decision process. S/ he also needs to carry out traditional ceremonies by providing food as a banquet to the villagers,

${ }^{22}$ Amirsyam, Gayo Traditional Leader, Takengon, interviewed on February 9th, 2018 
begs forgiveness of Allah swt and asks for apologize to the local community. ${ }^{23}$

When viewing at the principle of willingness to do customary sanction stipulated in Gayo customary law, the community is expected to understand that customary law is a form of lecturing, not punishment. The goal is to make the community, consisting of the customary violator, family and surrounding people who inhabit a customary law area can realize and respect the values preserved by their ancestors.

The development of the legal system in Indonesia surely provides an alternative for the community in resolving disputes social life of the community. Here, customary law, together with national law, regulates the settlement of various disputes, provides protection, and guarantees legal certainty. This is where legal pluralism in which other legal systems outside the laws of the state living in society is much recognized to realize the values of justice based on humanity.

The implementation of customary sanction is expected to be in line with humanitarian principles instead of punitive or judgemental so that in its implementation, it can become a judicial jurisdiction aimed at fostering the community. Additionally, it must be carried out wisely by putting aside personal and group interests and performed as mandated in the Central Aceh District Qanun Number 10 of 2002 concerning Gayo Customary Law. The implementation of customary sanction in accordance with the provisions stipulated in the qanun is a form of respect and protection of the values of human rights.

\section{Constraints and Obstacles Faced by Customary Institutions of Sarak Opat in the Implementation of Customary Sanction}

\section{Constraints}

Central Aceh District inhabited by a majority of the Gayo population has customary law and tradition which in its development required legal codification. The consequence of this is the form of Qanun of Central Aceh District Number 10 of 2002 concerning Gayo

23 Abdul Muthalib, Community Leader of Asir-Asir Atas Village, Takengon, interviewed on February $8^{\text {th }}, 2018$ 
Customary Law. The qanun regulates the role of the Sarak Opat traditional institution as a government institution at the village level.

The need for improving the quality of human resources for officials of the traditional Sarak Opat institution consisting of reje, petue, imem, and rakyat genap mupakat is one of them. The lack of understanding and capacity of custom instruments on customary law is caused by several factors, including the influence of modernization, the age of custom instruments which tends to be young and the absence of rules requiring reje candidates as elements of customary law to understand customary law before being appointed.

In addition to these constraints, the lack of knowledge on customary provisions and the implementation of customary sanction among community members is another challenge for the traditional Sarak Opat institution. The influence of cultural assimilation is one of factors that influence the mindset of nowadays people who tend to be individualistic. This reduces the appreciation of spirit and meaning of the family that had been developed in Gayo customary law.

\section{Obstacles}

The existence of customary law as a law that grows, lives and develops in Indonesia is increasingly marginalized. The customary law which was originally a law that was considered capable of providing solutions to various problems in the life of Indonesian people, especially its existence, has gradually been faded. ${ }^{24}$ At the present time, various obstacles are faced by indigenous people of Indonesia when customary law is confronted with positive law, such as when the traditional rights of the community copes with the interests of investors through the means of state law. ${ }^{25}$

The development of the Indonesian legal system which tends to lead to the codification and unification of the law accelerates the disappearance of the customary law institutions. In fact, it cannot be denied that this is currently related to the application of customary sanction which for some people is considered contrary to human

24 Lastuti Abubakar, "Revitalisasi Hukum Adat sebagai sumber Hukum dalam Membangun Sistem Hukum Indonesia", Journal of Dynamic Law, Vol.13 No.2 (May 2013).

${ }^{25}$ M. Syamsudin, "Beban Masyarakat Adat Menghadapi Hukum Negara", Journal of Law, Vol. 15 (July 3rd, 2008), 338. 
values, such as the sanction for expulsion when done arbitrarily. This becomes an obstacle for customary institutions which adhere to customary provisions and impose customary sanction for violators, as perceived by the traditional Sarak Opat institutions in Central Aceh. They play a role in preventing and prosecuting illegal acts (sumang), implementing customary law, tradition, customary sanction and resolving cases that violate custom. For some people, it is argued that sanction for imposing fines on perpetrators who violate custom is a form of extortion which Indonesian law constitutes it as a criminal offence.

The Sarak Opat institution as the head of the custom leader in the village finds obstacles in implementing customary law because customary law-which should indeed be unwritten-begins to experience a shift along with the presence of written state law as it is considered to provide more legal certainty. The Sarak Opat institution also realizes that it becomes difficult today to implement customary law such as strife in households that often ends up in a religious court with divorce status without any initial mediation by a traditional leader. ${ }^{26}$

Basically, customary law, which is a series of norms governing community behavior, is a manifestation of human rights values. This is particularly because every applied customary law is appropriate and agreed upon by people of a region through the process of taking the principles of justice and humanity into account. In this case, one of the problems is the occurrence of errors in the application of law and customary sanction that have not been in accordance with the substance set out in the qanun. Furthermore, it would certainly give an impact on the function of customary institutions which are abused in the name of customary law. On this basis, a set of condition is needed for prospective leaders of customary institutions. In addition to integrity, they must also master the knowledge of customary law in their area so everytome there found any case in the society, they can wisely make a decision. ${ }^{27}$ The implementation of customary law needs

\footnotetext{
${ }^{26}$ Tgk. Yahya, Petue of Asir-Asir Atas Village, Takengon, interviewed on February $8^{\text {th }}$, 2018

${ }^{27}$ Daud Yoesoef, Deputy Chair of the Acehnese Customary Assembly, interviewed in Banda Aceh on February 19th, 2018
} 
elaboration in a clear form of regulation so that everyone, especially the official instruments, can understand and agree on customary provisions that are final and binding.

Another obstacle faced by the Sarak Opat institution is that there are still many parties acting on behalf of the community in taking anarchic actions to resolve traditional disputes, such as vigilanteism and violence during the expulsion process. ${ }^{28}$ This is a big challenge to make people understand on the procedures for overcoming customary disputes and avoid them to reduce or even eliminate peace as the basic essence of customary law.

Based on the constraints and obstacles outlined above, it can be analyzed that each component of customary law enforcement, both regular and customary instruments must be updated in accordance with the demands of the era. Among others, the demands consist of debriefing customary instruments which are related to knowledge of previous traditional values, raised in a customary regulation, agreed and codified in written rules then understood and implemented by indigenous groups.

The government is responsible for providing legal protection and assistance for indigenous law groups with the good capacity building through education and socialization. It would make the existence of customary law remain in line with the desired legal concept of the state. This is stated in the Presidential Regulation Number 33 of 2018 concerning Amendments to Presidential Regulation Number 75 of 2015 concerning National Human Rights Action Plans for 2015-2019.

The constraints and obstacles in the implementation of customary law are handled by improving the capacity of human resources. Additionally, it needs to direct the formation of traditional instruments in accordance with ancestral values but can still be applied in social life and. They must also be peaceful to create a harmonious legal system as well compatible as an alternative in completing community social matters.

\footnotetext{
${ }^{28}$ Ibnu Hajar, Reje of Bujang Village, Takengon, interviewed on February $7^{\text {th }}, 2018$
} 


\section{Conclusion}

Traditional dispute resolution is still carried out by most of Gayo people by applying a family approach. This is in line with ancestral values and humanitarian principles so that a provision that has been agreed upon and carried out with full willingness is believed to maintain the social stability inside or outside the community. In its development, Gayo customary law is considered necessary to continue to be guarded and studied so that efforts are required to conduct the transcription of customary rules which have been passed down. Therefore, it can be further understood and known by the entire community with the goal of providing legal certainty for all indigenous people.

Constraints and obstacles related to the implementation of customary sanction by the traditional Sarak Opat institution in Central Aceh District are caused by several factors. Among others, it is because the unsteady position of customary law which is not the same as the positive law with its more legal certainty. This is a challenge for customary law to maintain itself for the existence in the middle of nowadays diverse and plural societies. Judging from human resource capabilities, the obstacle of implementing customary law is mainly about the lack of understanding on the custom instruments against customary law. This is caused by several factors, including the influence of modernization, the age of customary instruments which currently tends to be young and the absence of mandatorily rules required for keuchik/reje candidates as the executive of customary law to undergo qualification and capacity tests before being appointed.

\section{Bibliography}

Abu Bakar, Al-Yasa'. Syari'at Islam di Nanggroe Aceh Darussalam, Paradigma Kebijakan dan Kegiatan, Dinas Syari'at Islam Provinsi Nanggroe Aceh Darussalam, Banda Aceh, 2005

Abubakar, Lastuti. Revitalisasi Hukum Adat sebagai sumber Hukum dalam Membangun Sistem Hukum Indonesia, Jurnal Dinamika Hukum, Vol. 13 No. 2 (Mei 2013). http://dx.doi.org/10.20884/1.jdh.2013.13.2.213

Ahmad Zein, Yahya . Nurvianti, Dewi. "Konsepsi Hak Masyarakat Hukum Adat Sebagai Hak Asasi Manusia", Fakultas Hukum 
Universitas Borneo Tarakan, Vol. 3 No. 2 (2017) http://dx.doi.org/10.25123/vej.2689

Darmawan, "Peranan sarak Opat dalam Masyarakat Gayo", Jurnal Kanun, Vol. 12 Nomor 1, (Edisi April 2010). https:// doi.org/10.24815/kanun.v12i1.6289

http://dx.doi.org/10.30821/miqot.v38i1.98

Muhammad, Bushar. Asas- asas Hukum Adat suatu pengantar, cet XII, Pradnya Paramita, Jakarta, 2003

Muhammad, Rusydi Ali. Revitalisasi Syaria'at Islam di Aceh Problem, Solusi dan Implementasi menuju Pelaksanaan Hukum Islam di Nanggroe Aceh Darussalam, Cet. I, Logos Wahana Ilmu, Jakarta, 2003

Murdan, "Pluralisme Hukum (Adat dan Islam) di Indonesia", Mahkamah: Jurnal Kajian Hukum Islam, Vol 1 No. 1 (Tahun 2016). http://dx.doi.org/10.24235/mahkamah.v1i1.573

Safrijal, Airi. "Penerapan Sanksi Adat dalam Penyelesaian Perkara Pidana di Kabupaten Nagan Raya". Jurnal Kanun Ilmu Hukum, Volume No. 15 Nomor 1 (Tahun 2013). https://doi.org/10.24815/kanun.v15i1.6165

Soedjatmoko, Pembangunan dan Kebebasan, Jakarta: LP3ES, 1984

Sukiman: "Nilai-Nilai Pembangunan Islam dalam Masyarakat Adat Gayo", Miqoot, Vol. XXXVIII No.1 (Januari- Juni 2014).

Susylawati, Eka. "Eksistensi Hukum Adat dalam Sistem Hukum di Indonesia", Jurnal Al Ihkam, Vol. IV No.1, (Juni 2009).

Syahbandir, Mahdi. "Kedudukan Hukum Adat dalam Sistem Hukum", Jurnal Kanun Vol. 12 No.1 (Edisi April 2010), https://doi.org/10.24815/kanun.v12i1.6285

Syamsudin. M, "Beban Masyarakat Adat Menghadapi Hukum Negara", Jurnal Hukum, Vol. 15 No. 3 (Juli 2008). https:// doi.org/10.20885/iustum.vol15.iss3.art9

Syukri, Sarakopat: Sistem Pemerintahan Tanah Gayo Dan Relevansinya Terhadap Pelaksanaan Otonomi Daerah Jakarta: Hijri Pustaka Utama, 2006

Taqwaddin, "Penyelesaian Sengketa/ Perselisihan secara Adat Gampong di Aceh", Jurnal Kanun Ilmu Hukum, Vol. 17 No.3, (Des, 2015) https:// doi.org/10.24815/kanun.v17i3.6085 
Valentina Shanty, Adwani Adwani, Azhari Yahya

Taqwaddin, Kapita Selekta Hukum Adat Aceh dan Qanun Wali Nanggroe, Bandar Publishing, Syiah Kuala, banda Aceh, 2013

Wijayanti, Asri dan Achmad, Lilik Sofyan. Strategi Penulisan Hukum, Lubuk Agung, Bandung, 2011 